\section{First Meeting of the Portuguese Society for Developmental Biology (SPBD)}

\author{
Oeiras, 27-28 October 2006
}

The $1^{\text {st }}$ Meeting of the Portuguese Society for Developmental Biology (SPBD - Sociedade Portuguesa de Biologia do Desenvolvimento; Fig. 1) was held during two sunny autumn days at the Instituto Gulbenkian de Ciência (IGC) (Fig. 2A) located in the beautiful seaside city of Oeiras (Fig. 2 B,C). This small meeting provided unprecedented conditions for Portuguese Developmental Biology researchers to know what is being done in Portugal, to receive feedback on their own work and to establish strong and productive national collaborations. One of the high points of the meeting was the official launching of the SPBD by its President /sabel Palmeirim (Fig. 2E) and the announcement of the SPBD website (www.spbd.org) recently created with the purpose of developing and promoting Developmental Biology in Portugal.

The meeting was attended by 77 delegates representing 18 research groups, $71 \%$ of which were women and solely $29 \%$ were men. In fact, this proportion corresponds to the average gender distribution of Biological Science researchers in Portugal. The Developmental Biology field is quite recent in our country and started off when young Portuguese researchers, working in this field abroad, returned to their home country and established their own research groups. For this reason, it is not a surprise to see that $64 \%$ of the delegates were under the age of 40 years.

We were very pleased to have the presence of Julian Lewis (CRUK) presenting the meeting's opening lecture entitled "Feedback loops in the Notch pathway: generating patterns in space and time". He considers that

It was a real privilege and a great pleasure to take part in

this inaugural meeting. The audience was young, lively and enthusiastic; the discussions were lively and the science was excellent. I enjoyed myself and learned a lot and Ilook forward to an exciting future for the Portuguese Society for Developmental Biology.

Claudio Stern (UCL) honoured us with the meeting's closing lecture entitled "Making a brain: a molecular dissection of neural induction". He wrote,

Witnessing the birth of a new society is a very rare pleasure.

I mentioned in my talk the strong parallels between this society and its long-established British counterpart (the BSDB - see Slack, J.M.W. [2000] A short history of the British Society for Developmental Biology. Int J Dev Biol.

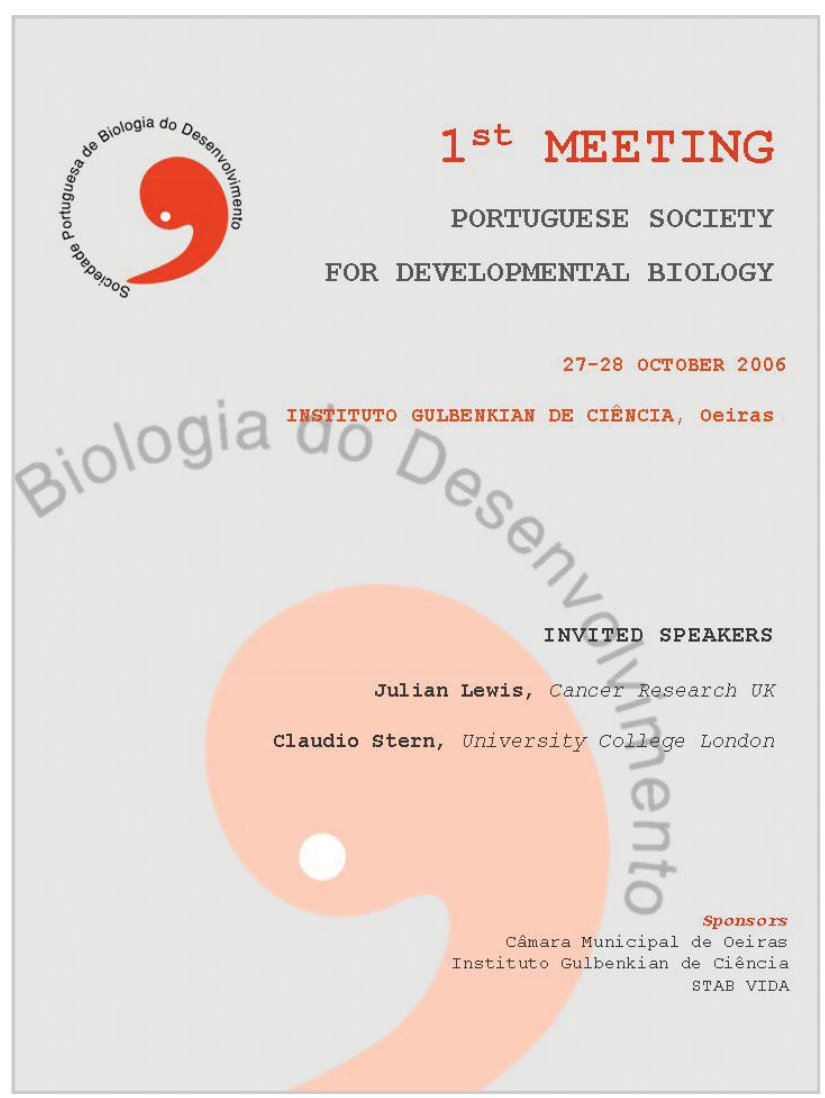

Fig. 1. Poster of the $1^{\text {st }}$ Meeting of the Portuguese Society for Developmental Biology.

44: 79-83) - both started as an informal «club» with a few people getting together to discuss their results and then evolved into a full-fledged professional society. But this one is even more unique - one could not fail to be impressed by the tremendous enthusiasm of such a large number of keen young scientists, by the huge effort invested by everyone into preparing truly superb talks and posters, by the sheer energy and commitment of all those who attended the meeting and by the efficiency of the organizers. The team spirit and strong desire of the participants to create a society to represent them was overwhelming and highly contagious. If this meeting is anything to go by, the Portu-

Abbreviations used in this paper: CBME-UA, Centre for Molecular and Structural Biomedicine, Universidade do Algarve; CRUK, Cancer Research UK; FCUL, Faculdade de Ciências da Universidade de Lisboa; FMV, Faculdade de Medicina Veterinária da Universidade Técnica de Lisboa; ICVS, Life and Health Sciences Research Institute, University of Minho; IGC, Instituto Gulbenkian de Ciência; IMM, Instituto de Medicina Molecular; ISCEM, Instituto Superior Ciências da Saúde Egas Moniz; ITQB, Instituto de Tecnologia Química e Biológica; UCL, University College London, UK. 
guese Society has a very bright future indeed and the $B S D B$ and other national societies will have a lot to learn from it.

The scientific communications presented orally and discussed during the SPBD meeting included many different subjects and model systems

\section{When intuition is not enough}

In his opening lecture, Julian Lewis (CRUK) put forward the idea that "in order to understand complex biological behaviors, unaided intuition is not enough: we need mathematics". This combination of experimental data and maths was revisited again latter in the SPDB meeting when Filipa Alves (presently a postdoc at José Feijós lab, IGC) presented her PhD work on a mathematical model describing the establishment of segmental patterning of maternal and gap proteins in the Drosophila embryo (Alves \& Dilão, 2006).

\section{Biological clocks}

Julian Lewis also raised and discussed a central question in biology: how is time controlled during embryogenesis? The only clock known so far to operate during embryonic development is the segmentation clock (reviewed in Freitas et al., 2005). This molecular clock, in the form of a transcription oscillator, operates in the presomitic mesoderm (PSM) with the same periodicity as somite formation and constitutes an excellent framework to tackle temporal control during development. It was previously though that a negative feedback loop in which the expression of a gene is repressed by its own protein product would be insufficient to generate/maintain sustained oscillations (Hirata et al., 2002). Julian Lewis used the power of mathematics to show that mRNA and protein oscillations can be produced if transcriptional and translational delays are taken into account (Lewis, 2003; Monk, 2003). Nevertheless, delayed feedback will only set up the pace of oscillations if the mRNA and protein half-lives are effectively small in relation to the delay. Using high-resolution wholemount in situprotocols to detect the sub-cellular expression of the cycling genes, Julian Lewis showed that such delays exist at the level of PSM cells.

A fascinating possibility is that the same clock mechanism might be used to measure time in a broader variety of cell types, other than the PSM. In agreement with this hypothesis, Susana Pascoal (Isabel Palmeirim's lab, ICVS) provided the first evidence for a molecular clock operating at the level of chick forelimb bud. She showed that the somitogenesis clock component hairy2 oscillates in autopod chondrogenic precursor cells with a 6-hour periodicity and that an autopod skeletal element is formed by cells that escape Fgf8 influence concomitantly with two cycles of hairy2 expression (Pascoal et al., 2007).

The limbs, as well as the pectoral fins, are paired appendages that constitute an important evolutionary accomplishment of vertebrates. The fossil records show that early vertebrates have well-developed median fins with no paired fins, suggesting the possibility that the developmental mechanisms of fin formation were first gathered at the embryo midline. Using shark and lamprey embryos, Renata Freitas (Martin J. Cohn's lab, University of Florida)showed that, in contrast to paired fins that originate from the lateral plate mesoderm (LPM), median fins derive mainly from somitic mesoderm. Although different in origin, median and pectoral fins share the same developmental mechanisms of fin development assessed by the expression of Hox and Tbx genes (Freitas et al., 2006). These results reveal that the genetic program of fin development originates first in the somitic mesoderm and then is re-used in the LPM allowing the formation of paired fins. If we combine the results presented by Susana Pascoaland Renata Freitas, it is very tempting to speculate that the somitogenesis clock could also be part of the re-used genetic program that allowed the appearance of paired appendages.

\section{Somite formation and differentiation}

Ultimately, somitogenesis is a complex morphological process that transforms undifferentiated mesenchymal PSM cells into a sphere of polarized epithelial cells with a few mesenchymal cells in the lumen. When PSM cells approach the rostral third of the PSM, clock genes cease to cycle, the extracellular matrix (ECM) environment changes and rostral PSM cells undergo a mesenchyme to epithelium transition (MET), forming a new pair of somites (reviewed in Freitas et al., 2005). It has long been thought that a factor from the ectoderm is necessary for MET to occur since removal of the ectoderm leads to a failure in epithelialisation (Sosic et al., 1997). However, Gabriela Rodrigues (Sólveig Thorsteinsdóttir's lab, FCUL) showed that enzymatic methods commonly used to separate the ectoderm from the PSM, destroy the endogenous ECM and methods that leave the ECM intact allow somite formation in the absence of ectoderm. This strongly suggests that the ECM is crucial for the MET process. However, little is know about the nature of the ECM within the PSM and nothing is known about how the ECM modulates PSM cell behavior. To understand these questions, Gabrie/Martins (Sólveig Thorsteinsdóttir's lab, FCUL) developed a high-resolution 3D imaging technique that will allow the characterization of cell-cell and cell-matrix interactions in the PSM as it happens in vivo.

Once they are formed, the somites initiate a process of differentiation that will result in the formation of all different types of vertebrae (cervical, thoracic, lumbar, sacral and caudal). The current view is that cervical to caudal identity of the vertebrae is determined by the expression of specific combinations of Hox genes in the somites. Using a transgenic approach in mice, Moisés Mallo (IGC) challenged this idea by showing that the Hox genes are patterning the vertebrae at the level of the PSM and not at the level of the already formed somites (Carapuço et al., 2005).

\section{Cell polarity across species}

Understand how cells establish and maintain polarity is essential to comprehend many biological processes like asymmetric cell division, directed cell migration and epithelial formation. It has been known for a long time that cell division can switch from a medial to an asymmetric mode when bacteria need to form a spore. Using Bacillus subtilis as a model organism, Adriano

Fig. 2. Souvenirs from the $\mathbf{1}^{\text {st }}$ Meeting of the Portuguese Society for Developmental Biology. (A) The Gulbenkian Science Institute, Oeiras, where the meeting was celebrated. (B,C) The seashore at Oeiras. (D) The 2006 SPBD family photo. (E,F) Overview of the conference room. (G) The winner of the Best Poster Prize, Marta Carapuço from the laboratory of Moises Mallo, IGC . (H) Farewell dinner. 

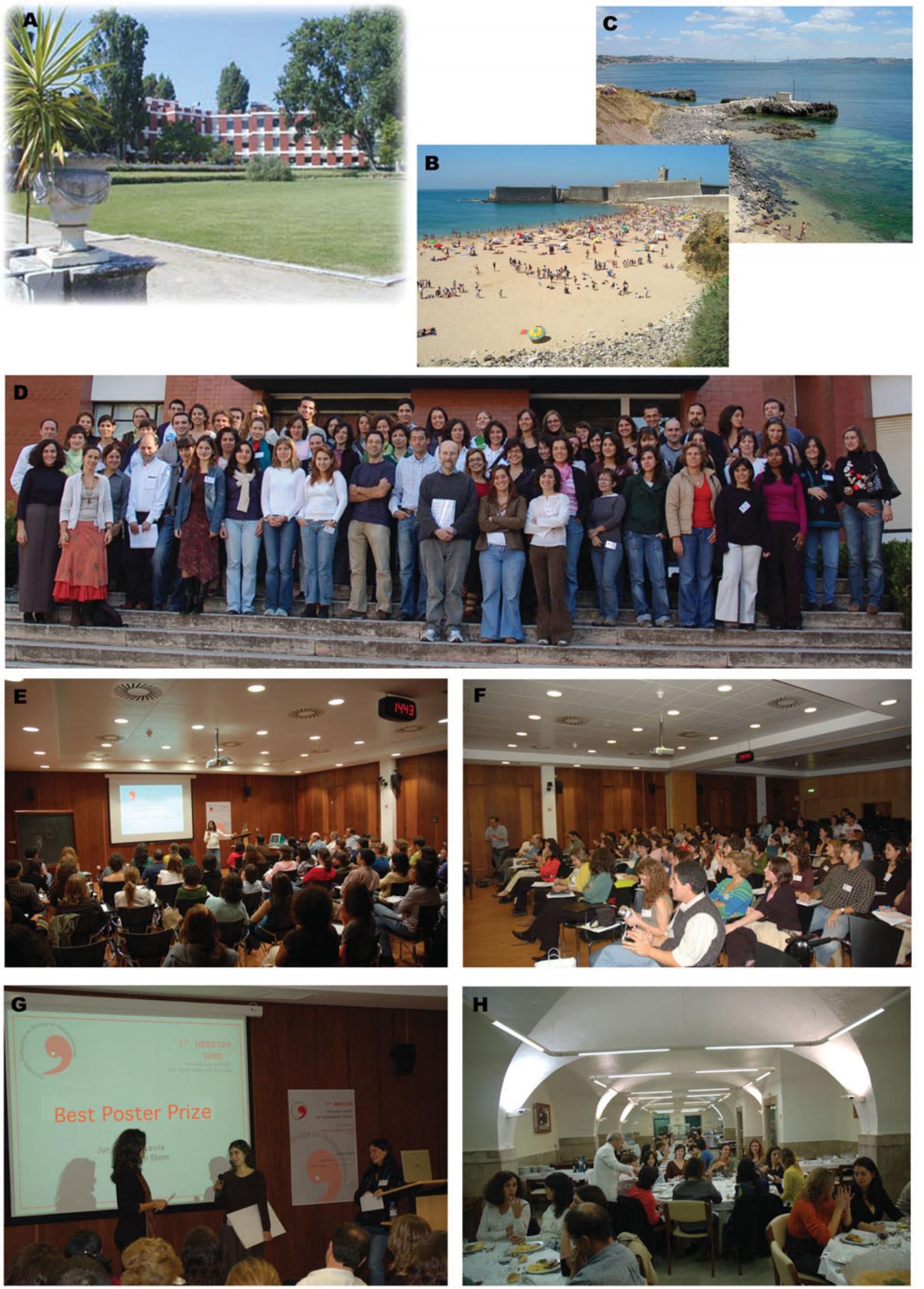
Henriques (ITQB) showed the importance of coordinating asymmetric division with pre-spore chromosome segregation.

Asymmetric cell division might also be a key feature of the process that originates a variety of neurons and glia from neural stem cells in the developing central nervous system in vertebrates. Once we identify the molecules asymmetrically localised within neural stem cells during division and/or differentiation we will be closer to understand the biology of neural stem cells. Evguenia Bekman (Domingos Henrique's lab, IMM) developed a gene-trap strategy to identify gene products with a polarized distribution in the neural precursor cells generated from pluripotent embryonic stem cells (ES). Further characterization of the already successfully isolated ES clones with specific sub-cellular localizations will help to elucidate neuronal differentiation.

Epithelial cells can show two types of polarization: apicalbasolateral polarity enabling directed protein trafficking and planar cell polarity (PCP) essential for tissue functioning (Wang and Nathans, 2007). Isabel Barahona (ISCSEM) used a yeast twohybrid system to identify chick proteins that interact with Prickle, a central component of PCP signaling pathway.

The early Drosophila embryo is a syncytium that through a process called blastoderm cellularization becomes a polarized epithelium. During cellularization adjacent cells begin to form polarized cell-cell contacts. Rui Tostões (Rui Martinho's lab, IGC) has been involved in the characterization of a novel collection of maternal mutants defective for blastoderm cellularization that constitute an excellent opportunity to uncover new genes involved in cell polarity.

\section{Cell division, a fundamental event in embryonic develop- ment}

A variety of human diseases such as anomalous organ positioning inside the body cavities, cancer and infertility are associated with abnormal centrosome number and function. Recently, it was shown that in transformed cells, the excess of centrosomes may arise through a pathway that does not use them as templates and therefore has been named the "de novo centrosome formation" pathway. Using the fly as a model organism, Mónica Bettencourt-Dias (IGC) reported a molecular mechanism that controls templated and de novo centrosome biogenesis. In a series of depletion and overexpression experiments, she showed that SAK/PLK4, a member of the polo-like kinase family, is a master regulator of centrosome biogenesis, being involved in both pathways.

\section{Mammalian vascular development}

António Duarte (FMV)discussed the role of Notch signalling in mammalian vascular development. The analysis of D//4gain- and loss-of-function mouse mutants showed that this ligand is required in a dosage-dependent manner for normal arterial identity (Duarte et al., 2004). His group analyzed in detail the endothelial gene expression patterns and the cellular effects in these mutants to try to unveil the way Notch signalling exerts its effect on endothelial cells and to understand ultimately D//4 function in mammalian arteriogenesis and in the regulation of vessel branching in general.

\section{Timing of neural induction}

Classical experiments in the frog embryo led to the idea that neural induction depends on the activity of BMP antagonists secreted by the organizer leading to the "default model". However, results from other organisms suggest that this model may be too simplistic and that neural induction is not a simple one step process (reviewed in Stern, 2006). Instead, it seems to be tightly controlled in time and to involve the co-operation of different classes of signals provided by different embryonic regions as discussed by José António Belo (CBME-UA) and Claudio Stern (UCL).

A neural plate still forms even when the organizer is surgically ablated in frog, chick, zebrafish and mouse gastrula embryos, indicating that neural inducing signals derive from tissues other then the organizer or in addition to the organizer (reviewed in Wilson and Edlund, 2001). The anterior visceral endoderm (AVE) is an extra-embryonic tissue that has been implicated in anterior neural induction in the mouse. However, several lines of evidence are pointing to the idea that rather than inducing actively forebrain character, the AVE protects prospective forebrain cells form caudalizing signals (Martinez-Barbera et al., 2000; Stern, 2001). José António Belo (CBME-UA) wants to further characterize the molecular mechanisms that play a role in anterior patterning. To achieve this, his group developed a transgenic mouse line expressing EGFP specifically in the AVE. This transgenic line enabled the micro-dissection of the AVE and the diametrically opposed region and then compared these two regions using microarrays. This approach led to the identification of a number of new transcripts that might play a role in anterior patterning at early stages.

Another possibility to explain why the removal of the organizer does not compromise the generation of neural tissue is that specification of neural cells is initiated before gastrulation, an idea put forward by Claudio Stern (UCL). Work from Stern's laboratory and others (Streit etal., 2000; Wilson etal., 2000) have shown that FGF signalling is required to initiate neural induction before gastrulation. In his talk, Claudio Stern discussed the timing of FGF action since this molecule is required not only for neural induction, but also for mesoderm formation. He proposed a model in which FGF initiates mesoderm and early proneural markers and soon after induces the zinc-finger protein Churchill that in turn inhibits mesoderm allowing the stabilization of a neural plate fate (Sheng et al., 2003). To increase the level of control, a new short coiledcoil protein called BERT seems to delay the progression to committed neural plate while mesoderm is still being induced.

\section{Best Poster Prize Attribution}

Two poster sessions were held where 36 posters, dedicated to a broad spectrum of scientific research topics, were presented, namely: tissue regeneration and morphogenesis, somitogenesis, myotome formation, stem cell biology, axial skeleton patterning, cell cycle, cell polarity, neurogenesis, left-right symmetry, cardiovascular development, blood lineage development, lung morphogenesis, head formation, limb development, retina development, ions in development, angiogenesis and arteriogenesis, follicle formation and loss. Different animal models were used (Drosophila, Xenopus, zebrafish, chick, mouse and rat), as well as many different technical approaches: standard molecular biology techniques (gene misexpression, RNAi, morpholinos, in situ hybridization, real-time single cell gene expression monitoring, pro- 
moter analyses, microarrays, ChIP-on-chip assays), ultrasoundguided in uteroadenoviral injections, yeast two-hybrid and mutant screen assays, transgenic embryo production, lineage tracing, immunohistochemistry and time-lapse confocal imaging. However, at the end the jury composed by Julian Lewis and Claudio Stern had no doubts to attribute "The Best Poster Prize" to Marta Carapuço (Moises Mallo's lab, IGC) for her work entitled "Patterning roles of Hox genes in the axial skeleton" (Fig. 2G).

\section{Conclusion}

This $1^{\text {st }}$ Meeting of the Portuguese Society for Developmental Biology was felt by all to be a success and a step forward in a long and very productive journey of Developmental Biology research and communication in Portugal. The meeting organizers wish to acknowledge the financial support offered by IGC, STAB VIDA, Banco Espírito Santo (BES) and the tasty farewell dinner offered by Oeiras City Hall, held at the beautiful Palácio do Marquês. We end with a quote from Isabel Palmeirim, our current SPBD President:

"Given that this meeting aimed to launch our recently created Society, it was very encouraging to see an already

\begin{abstract}
critical number of young enthusiastic Portuguese Developmental Biologists that participated in a very passionate way in our initiative and are performing high quality science. These certify an excellent future for the Portuguese Society for Developmental Biology! “
\end{abstract}

Raquel P. Andrade ${ }^{1}$ and Leonor Saúde ${ }^{\star 2}$

${ }^{1}$ Life and Health Sciences Research Institute (ICVS), School of Health Sciences, University of Minho, 4710-057 Braga, Portugal.

${ }^{2}$ Instituto Gulbenkian de Ciência, Centro de Biologia do Desenvolvimento, Rua da Quinta Grande 6, 2780-156 Oeiras, Portugal.

*Corresponding author:Leonor Saúde.e-mail:mlsaude@igc.gulbenkian.pt

\section{Acknowledgements}

We would like to thank Nuno Afonso, Rita Fior, Susana Pascoal and Isabel Palmeirim for input and corrections on the manuscript. RPA and $L S$ are funded by FCT, Portugal (grants no. SFRH/BPD/9432/2002 and SFRH/BPD/6755/2001, respectively).

KEY WORDS: SPBD, development, Portugal

\section{References}

ALVES, F. and DILÃO, R. (2006). Modeling segmental patterning in Drosophila: Maternal and gap genes. J. Theor. Biol. 241(2): 342-359.

CARAPUÇO, M., NOVOA, A., BOBOLA, N. and MALLO, M. (2005). Hox genes specify vertebral types in the presomitic mesoderm. Genes Dev. 19(18):21162121.

DUARTE, A., HIRASHIMA, M., BENEDITO, R., TRINDADE, A., DINIZ, P., BEKMAN, E., COSTA, L., HENRIQUE, D. and ROSSANT, J. (2004). Dosage-sensitive requirement for mouse DII4 in artery development. Genes Dev. 18(20):24742478.

FREITAS, C., RODRIGUES, S., SAÚDE, L. and PALMEIRIM, I. (2005). Running after the clock. Int. J. Dev. Biol. 49(2-3):317-324.

FREITAS, R., ZHANG, G. and COHN, M. J. (2006). Evidence that mechanisms of fin development evolved in the midline of early vertebrates. Nature 442(7106): 1033-1037.

HIRATA, H., YOSHIURA, S., OHTSUKA, T., BESSHO, Y., HARADA, T., Yoshikawa, $\mathrm{K}$. and KAGEYAMA, R. (2002). Oscillatory expression of the bHLH factor Hes 1 regulated by a negative feedback loop. Science 298(5594): 840-843.

LEWIS, J. (2003). Autoinhibition with transcriptional delay: a simple mechanism for the zebrafish somitogenesis oscillator. Curr. Biol. 13(16):1398-1408.

MARTINEZ-BARBERA, J. P., CLEMENTS, M., THOMAS, P., RODRIGUEZ, T., MELOY, D., KIOUSSIS, D. and BEDDINGTON, R. S. (2000). The homeobox gene $\mathrm{Hex}$ is required in definitive endodermal tissues for normal forebrain, liver and thyroid formation. Development 127(11):2433-45.

MONK, N. A. (2003). Oscillatory expression of Hes1, p53 and NF-kappaB driven by transcriptional time delays. Curr. Biol. 13(16): 1409-1413.

PASCOAL, S., CARVALHO, C. R., RODRIGUEZ-LÉON, J., DELPHINI, M. C.,
DUPREZ, D., THORSTEINSDÓTTIR, S. and PALMEIRIM, I. (2007). A molecular clock operates during proximal-distal limb outgrowth in the chick embryo. $J M B$, doi:10.1016/j.jmb.2007.01.089.

SLACK, J.M.W. (2000) A short history of the British Society for Developmental Biology. Int J Dev Biol. 44: 79-83.

SOSIC, D., BRAND-SABERI, B., SCHMIDT, C., CHRIST, B. and OLSON, E. N (1997). Regulation of paraxis expression and somite formation by ectodermand neural tube-derived signals. Dev. Biol. 185(2): 229-243.

STREIT, A., BERLINER, A. J., PAPANAYOTOU, C., SIRULNIK, A. and STERN, C. D. (2000). Initiation of neural induction by FGF signalling before gastrulation. Nature 406(6791): 74-78.

STERN, C. (2006). Neural induction: 10 years on since the "default model". Curr. Opin. Cell Biol. 18: 692-697.

STERN, C. D. (2001). Initial patterning of the central nervous system: how many organizers? Nat. Rev. Neurosci. 2. 92-98.

WANG, Y. and NATHANS, J. (2007). Tissue/planar cell polarity in vertebrates: new insights and new questions. Develop. 134: 647-658.

WILSON, S. I. and EDLUND, T. (2001). Neural induction: towards a unifying mechanism. Nat Neurosci. 4 (Suppl): 1161-1168.

WILSON, S. I, GRAZIANO, E., HARLAND, R., JESSELL, T. M. and EDLUND, T. (2000). An early requirement for FGF signalling in the acquisition of neural cell fate in the chick embryo. Curr Biol. 10(8): 421-429.

SHENG, G., dos REIS, M. and STERN, C. D. (2003). Churchill, a zinc finger transcriptional activator, regulates the transition between gastrulation and neurulation. Cel/ 115(5):603-613. 


\section{Related Int. J. Dev. Biol. articles}

See our forthcoming Special Issue "Developmental Biology in Hispania"(Spain \& Portugal) at: http://www.ijdb.ehu.es/ web/spcountries.php

5th Congress of the Spanish Society of Developmental Biology. Jaume Baguñà. Int. J. Dev. Biol. (2007) 51: 91-96

Eye development at the Houston "Fly Meeting". Amit Singh. Int. J. Dev. Biol. (2006) 50: 659-663

Where do we stand now? - mouse early embryo patterning meeting in Freiburg, Germany (2005). Takashi Hiiragi, Vernadeth B. Alarcon, Toshihiko Fujimori, Sophie Louvet-Vallée, Marek Maleszewski, Yusuke Marikawa, Bernard Maro and Davor Solter. Int. J. Dev. Biol. (2006) 50: 581-588

3rd Congress of the Spanish Society of Developmental Biology. Vol. 45 No. S1 (2001)

Head-tail patterning of the vertebrate embryo: one, two or many unresolved problems? Claudio D. Stern, Jeroen Charité, Jacqueline Deschamps, Denis Duboule, Anthony J. Durston, Marie Kmita, Jean-François Nicolas, Isabel Palmeirim, Jim C. Smith and Lewis Wolpert. Int. J. Dev. Biol. (2006) 50: 3-15

$\mathrm{N}$-acetylgalactosamine 4-sulfate 6-O-sulfotransferase expression during early mouse embryonic development. AnaMarisa Salgueiro, Mário Filipe and José-António Belo. Int. J. Dev. Biol. (2006) 50: 705-708

Developmental expression of Shisa-2 in Xenopus laevis. Ana-Cristina Silva, Mário Filipe, Marta Vitorino, Herbert Steinbeisser and José-António Belo. Int. J. Dev. Biol. (2006) 50: 575-579

The Le Douarin phenomenon: a shift in the paradigm of developmental self-tolerance. António Coutinholnt. J. Dev. Biol. (2005) 49: 131-136

Flower symmetry and shape in Antirrhinum. Jorge Almeida and Lisete Galego. Int. J. Dev. Biol. (2005) 49: 527-537

Gametophyte interaction and sexual reproduction: how plants make a zygote. Leonor C. Boavida, Ana Maria Vieira, Jörg D. Becker and José A. Feijó. Int. J. Dev. Biol. (2005) 49: 615-632

The making of gametes in higher plants. Leonor C. Boavida, Jörg D. Becker and José A. Feijó. Int. J. Dev. Biol. (2005) 49: 595-614

Developmental expression of chick twist and its regulation during limb patterning. A T Tavares, JC Izpisúja-Belmonte and J Rodriguez-León. Int. J. Dev. Biol. (2001) 45: 707-713

Age and gonadotropins control Ca2+-spike acquisition in mouse oocytes isolated from early preantral follicles. $J E$ Gomes, A Pesty, A Gouveia-Oliveira, A J Cidadão, C E Plancha and B Lefèvre. Int. J. Dev. Biol. (1999) 43: 839-842 